\title{
A high prevalence of human T-lymphotropic virus (HTLV I/2) infection among Afro-descendants, Esmeraldas province, Ecuador - need for the implementation of surveys and control programs
}

This article was published in the following Dove Press journal:

Infection and Drug Resistance

\section{Carmen Eulalia \\ Mosquera-Herrera ${ }^{1,2}$ \\ Elvia Piedad \\ Aspiazu-Miranda ${ }^{1,2}$ \\ Jacobus Henri de Waard ${ }^{3,4}$ \\ Miguel Angel \\ Garcia-Bereguiain ${ }^{3,5}$

\begin{abstract}
'Laboratorio de Virología, Instituto Nacional de Salud Pública e Investigación "Leopoldo Izquieta Pérez", Guayaquil, Ecuador; ${ }^{2}$ Facultad de Ciencias Médicas, Universidad de Guayaquil, Guayaquil, Ecuador; ${ }^{3}$ One Health Research Group, Facultad de Ciencias de la Salud, Universidad de Las Américas, Quito, Ecuador; ${ }^{4}$ Servicio Autónomo Instituto de Biomedicina, Universidad Central de Venezuela, Caracas, Venezuela; ${ }^{5} \mathrm{~S}$ chool of Biological Sciences and Engineering, Yachay Tech University, Urcuquí, Ecuador
\end{abstract}

Correspondence: Miguel Angel

Garcia-Bereguiain

One Health Research Group, Facultad de

Ciencias de la Salud, Universidad de Las

Américas, Calle Queri S/N 170504, Sede

Queri, Quito, Ecuador

Tel +593099648 4I27

Email magbereguiain@gmail.com
Background: Infection with the Human T-cell lymphotropic virus (HTLV) type 1 and 2 is endemic in South America. Although there are reports of the presence of these retroviruses in Ecuador, the infection is usually neglected in healthcare settings and by public health authorities, and no actualized prevalence data are available.

Objectives: This cross-sectional study aimed to estimate, using for the first time to our knowledge in Ecuador immunological and molecular biology methodologies, the prevalence of HTLV-1/2 infection in asymptomatic individuals from a potentially high-risk population of Afro-Ecuadorians in the Province of Esmeraldas.

Study design: Two hundred and twenty-seven plasma samples from asymptomatic individuals were analyzed for the detection of the HTLV-1/2 virus with three methods: a commercial ELISA, an indirect immunofluorescence (IF) assay, and a nested-PCR.

Results: The overall prevalence of HTLV-1/2 antibodies in this population, as determined with an ELISA, was $11.0 \%$. Both the IF assay and the nested-PCR confirmed a prevalence of $3.5 \%$.

Conclusion: The high prevalence of HTLV-1/2 infection among the Afro-Ecuadorian population of Esmeraldas Province shows the need of the implementation of control and prevention interventions to overcome the further dissemination of the infection. To define the real problem of HTLV-1/2 infection in Ecuador, more prevalence studies have to be undertaken in other Afro-Ecuadorian populations and high-risk populations like the indigenous population of the Andes Mountains and the tropical Amazon region.

Keywords: HTLV 1, HTLV2, Afro-descendants, Ecuador, ELISA, PCR

\section{Introduction}

The Human T-cell lymphotropic virus type 1 (HTLV-1) and type 2 (HTLV-2) have a worldwide distribution, with at least 5-10 million people infected. ${ }^{1-4}$ The prevalence depends on the geographical area, and endemic regions for HTLV-1/2 infection have been reported in Asia and Africa, in the Australo-Melanesian region and Caribbean region and South America. ${ }^{2,3,5-7}$ In non-endemic areas like Europe and North America, HTLV infection is uncommon and mainly found in the immigrants from endemic regions, and also mainly involving infection with the HTLV-1 virus. ${ }^{2,3,8}$ In South America, HTLV infection is endemic, present in all 13 countries, and prevailing in most ethnic populations. The human T-lymphotropic 
virus type 1 (HTLV-1) and type 2 (HTLV-2), although closely related, have a different geographical distribution. In the Americas, the HTLV-1 infection has more than one origin. The most important one, on a quantitative point of view, is very probably the slave trade from Africa during the colonial period. The more recent Japanese immigration in the early 20th century, despite being interesting, is considered less important. ${ }^{9}$ HTLV-2 is considered ancestral in the Americas and was brought in by immigrants through the Bering Strait. The type 2 virus consequently is widely distributed among the indigenous people of America, where it appears to be more prevalent than HTLV-1. ${ }^{9}$

HTLV type 1 and type 2 have different pathogenesis and clinical manifestations. HTLV-1 infections persist all life long and, although most of the patients are asymptomatic viral reservoirs, around $4-5 \%$ develop adult T-cell leukemia/lymphoma (ATLL), a highly aggressive CD4+ T-cell malignancy with poor prognosis. ${ }^{10}$ HTLV-1 has also been associated to a disabling myelopathy known as tropical spastic paraparesis or HTLV1-associated mielopathy (HAM/TSP), affecting $0.25-3 \%$ of the infected people depending on the geographical area., ${ }^{2,11,12}$ In contrast, HTLV-2 infection, also persisting for life, has not been clearly linked with pathologies, although the virus has been associated with some very rare cases of hairy cell leukemia, erythrodermatitis, and few cases of other neurological disorders. ${ }^{2,413}$ HTLV transmission is similar to other retrovirus like HIV, hepatitis $\mathrm{B}$, and $\mathrm{C}$ viruses. The most important routes of transmission are the mother-to-child transmission due to prolonged breast feeding, unsafe sexual habits, blood transfusion, and organ transplantation. ${ }^{2,7,14,15}$

The HTLV infection is usually neglected in healthcare settings and by public health authorities in South America, and the prevalence has been poorly investigated, especially in Ecuador. According to a recent technical report from the European Center for Disease Control and Prevention about the HTLV global distribution, Ecuador is considered a country with non-reliable data for HTLV epidemiology. ${ }^{2}$ There are several reports from other countries in South America, Brazil, and the neighbor countries, Peru and Colombia, showing a prevalence of HTLV-1 infection of up to $13.9 \%$ and a HTLV-2 infection rate of up to $57 \%$, especially in areas with a high presence of Afroamericans, ${ }^{7,16-19}$ and in Amerindian tribes. ${ }^{9}$ Infection with HTLV-1 is also reported among Japanese immigrants to Bolivia, Brazil, and Peru, and among their descendants. ${ }^{5,9}$ In these countries,
HTLV screening is currently performed in blood donors. ${ }^{7,8,18}$ to avoid further dissemination of the virus in the general population.

The only report in Ecuador about the epidemiology of HTLV dates from 1994 and comes from a small and mixed adult population of indigenous Amerindians and AfroEcuadorian people, and reports a Western blot confirmed prevalence of HTLV-1 infection of $2.8 \%{ }^{20}$ However, it is well known that prevalence studies of HTLV infection from the 1980s and 1990s were inaccurate due to the low sensitivity and specificity of the immunological assays used. ${ }^{2}$ In addition to this report, there are two publications showing clinical cases of TSP in the country associated with HTLV infection, ${ }^{21,22}$ and there is a recent report concerning the transmission of HTLV-1 from an infected kidney donor. ${ }^{15}$

The lack of information about the epidemiology of HTLV in Ecuador makes prevalence studies mandatory, and the aim of our study was to determine the HTLV-1/2 prevalence in a high-risk population of Afro-Ecuadorian $\mathrm{s}$ from the Esmeraldas province using methods that are more accurate and detect the DNA of the virus.

\section{Materials and methods}

\section{Study population and sample collection}

A total of 227 asymptomatic individuals with ages ranging from 16-71 years old (mean age $=40.55 \pm 16.03$; median age $=32$ years) from the Afro-Ecuadorian community of Borbon (Esmeraldas province) were enrolled in the study. Participation was voluntary, and recruitment was made through the Public Health Ministry local facility. The participants were interviewed, and information related to age, sex, and geographical origin was collected. Only participants confirmed to be Afro-Ecuadorian residents of the village of Borbon (2,601 habitants, according to the last census from 2010, from Instituto Nacional de Estadísticas y Censos) were entered in this study; 64 males and 163 females (8.73\% of total population). A peripheral blood sample was collected in a $5 \mathrm{~mL}$ tube with an anticoagulant (EDTA) following standard procedure.

\section{Blood sample processing}

Each $5 \mathrm{~mL}$ blood sample was divided in two: $2 \mathrm{~mL}$ was centrifuged for 5 minutes at 12,000 rpm for plasma isolation, and $3 \mathrm{~mL}$ was used for lymphocyte isolation using Lymphocyte Separation Medium (Lonza Walkersville Inc., USA) following supplier's indications. 


\section{ELISA HTLV I/2 detection}

Plasma samples were tested for HTLV with a commercial ELISA kit following manufacturer's instructions (DIALAB, Austria). According to the fabricant of the ELISA kit, the specificity of this assay is $99.99 \%$, and has been evaluated with a panel of samples obtained from 22,145 healthy blood donors from three blood banks. The sensitivity of the HTLV ELISA is set on $100 \%$ and has been tested with 125 HTLV $1 \& 2$ positive patients (105 HTLV-1 and 20 HTLV-2 samples) from patients with confirmed Western Blot and PCR positive results.

\section{Immunofluorescence and nested PCR HTLV I/2 detection}

Subjects positive for the ELISA were tested by an indirect immunofluorescence (IF) assay and nested PCR. For the IF assay, we followed the protocol supplied by the "Instituto Nacional de la Salud" from Chile, ${ }^{23,24}$ using MT-2 cells infected with HTLV-1 and non-infected Molt4 cells for plasma exposure.

For nested-PCR, DNA extraction from the buffy coat of the blood samples was performed using a QIAamp DNA Blood Mini Kit (QIAGEN, Netherlands) and the HTLV virus DNA was detected with an in-house nested-PCR following the protocols described elsewhere, ${ }^{25,26}$ using MT-2 cells infected with HTLV-1 as a positive control. Briefly, two sets of primers for the tax/rex gene were used: for the first PCR reaction the primers fw 5'-CGGATACCCAGTCTACGTGT-3' and rv 5'GAGCCGATAACGCGTCCATC-3' and for the nested-PCR reaction primers fw 5'-GTGTTTGGCGATTGTGTACA-3' and rv 5'-CCATCGATGGGGTCCCA-3'. Amplicons of 185 bp (first PCR) and 128 bp (nested PCR) were separated on $2 \%$ agarose gels stained with ethidium bromide and analyzed with imager Gel DoC XR system (BioRad). Tests used in this study do not differentiate between HTLV type 1 and type 2 infection.

\section{Ethics statement}

The Ethics Committee of the Instituto de Salud Pública e Investigación Leopoldo Izquieta Perez (Guayaquil, Ecuador) approved the study. All patients signed an informed consent (parents/guardians provided informed consent on behalf of all child participants) for the collection and storage of a blood sample and for the anonymous use of their data for research purposes. All patients received the results of their serological and PCR screening and full instructions on how to prevent transmission. The PCR and/or IF positive patients were examined by a medical officer to exclude any symptom of an HTLVrelated disease. This study was conducted in accordance with the Declaration of Helsinki.

\section{Results}

The results of the ELISA, the IF test, and the nested-PCR are summarized in Table 1. The commercial ELISA tested 25 patients out of 227 patients $(11.0 \%)$ as seropositive for HTLV-1/2.

These 25 ELISA positive patients were submitted to retesting, and eight were confirmed positive for both the IF and the nested-PCR tests. Five patients yielded an undetermined result for the IF test, but were negative for nested-PCR. No patients only positive for PCR were detected, resulting in a final prevalence of the infection with HTLV-1/2 of $3.5 \%(8 / 227)$. Three of these infected patients were women (ages 65, 52, and 48 years, with a medium age of $55,0 \pm 8,9$ years) and five were men (ages 64, 49, 56, 44, and 63 years, with a medium age of $55.2 \pm 8.7$ years). A medical exam of the patients by a physician showed no symptoms or signs of an HTLVrelated disease.

\section{Discussion}

In the present study, which enrolled 227 Afro-Ecuadorian subjects from Esmeraldas province in Ecuador, 25 were tested seropositive with an ELISA tests for HTLV-1/2, and eight patients were confirmed by an IF test and a positive nested-PCR result, defining a final prevalence of $3.5 \%$. There is an increase of prevalence for HTLV $1 / 2$ with age (55.12 \pm 8.11 years of mean age of the infected individuals compared to medium age of $40.55 \pm 16.03$ of the study population, $P<0.05)$. Although not statically significant, more men (five) were infected than women (three). According to the prevalence classification criteria of the European Centre for Disease Prevention and Control (ECDC), a prevalence over $1 \%$ in the population is considered a high prevalence. The ELISA test was used in this study as a first screening test for HTLV $1 / 2$ infection, and

Table I HTLV-I/2 testing with ELISA, IF, and nested-PCR for 227 subjects from a population of Afro-Ecuadorians in Esmeraldas, Ecuador

\begin{tabular}{|l|l|l|l|}
\hline Test result & ELISA test & IF test & Nested-PCR test \\
\hline Positive & $25(11.01 \%)$ & $8(3,52 \%)$ & $8(3,52 \%)$ \\
Negative & 202 & $214^{*}$ & 219 \\
\hline
\end{tabular}

Notes: $* 5$ cases were undertemined by IF.

Abbreviations: HTLV, human T-cell lymphotropic virus; IF, immunofluorescence. 
the IF and nested-PCR assay as confirmatory tests, as has been previously done in other studies. ${ }^{2,3,8}$ The low specificity of the ELISA test in our study is remarkable. With a specificity of $99.99 \%$, as reported by the manufacturer of this ELISA (see Materials and methods), 17 of the 237 subjects in this study were seropositive, but the infection could not be confirmed with the IF or nested PCR assay. We have no good explanation for this low confirmation, and of course we cannot exclude a low sensitivity of our retests, the IF test, and the PCR test. However, false positive ELISA results, caused by the infection with other microbial agents, especially Plasmodium falciparum, should be considered for this population. ${ }^{2}$ The Afro-Ecuadorian population of this study live in a Malaria endemic region. Also, in this endemic area, no infected subjects might have had contact with HTLV antigens and developed an immune response with production of specific antibodies that were detected in the ELISA. All our HTLV-1/2 infected subjects were confirmed to be asymptomatic. We suspect infection with the HTLV-1 virus in this population, as this is the most common infection in Afro-descendants in Latin America. ${ }^{9}$ However, as our tests did not differentiate between HTLV-1 and two infections, there is a need to confirm our results with a more specific test that differentiates between these two viruses. These tests are at this moment not available in the laboratories of the public health system in Ecuador. Concerning the prevalence of HTLV infection in Ecuador, there is only one other study published about 25 years ago, in 1994. Using ELISA and confirmation with Western blot, a population of 142 individuals with an Amerindian or Afro-Ecuadorian background was screened. ${ }^{20}$ This report showed a seroprevalence of $9.9 \%$ in the overall population and a confirmed prevalence with a Western blot of $2.8 \%$. No further studies were undertaken since 1994 to determine the prevalence in other high-risk group in the country, but Ecuador published three case reports concerning HTLV-1 infection in recent years. ${ }^{15,21,22}$

HTLV-1/2, especially HTLV-1 infection, has been associated with other Afro-descendent populations in the Americas. $^{2,3}$ According to a national census from 2010, Afro-descendants make up from 4-6\% of Ecuador's population, and the country has a population of approximately 1,120,000 descendants from African people. We, therefore, propose that other regions of Ecuador with a high density of an Afro-descendants should be studied to determine the prevalence of HTLV infection. HTLV infection in South America has also been found in another risk group, the native Amerindians. ${ }^{9}$ Although HTLV-2 infection is predominant among these individuals, HTLV-1 has been reported among Amerindian populations in Argentina, Bolivia, Chile, Colombia, Paraguay, and Peru. ${ }^{9}$ No information on HTLV infection among Ecuadorian Amerindians is available, although they represent $4 \%$ of the total population according to the last national census from 2010. We also claim for studies regarding the infection status in these vulnerable populations, and resources should be allocated for the execution of this research. In Peru and Colombia, both countries sharing borders with Ecuador, studies have shown that HTLV 1/2 infection is endemic and, in contrast with Ecuador, health authorities in these countries have included HTLV-1/2 screening for blood and organ donors. ${ }^{7,16-18}$ Actually, there is no HTLV$1 / 2$ screening for either blood or organ donors in Ecuador, although a recent case report showed transmission of HTLV-1/2 and development of TSP of a kidney transplantation patient from an infected donor. ${ }^{13}$

\section{Conclusion}

We show here that HTLV-1/2 infection is probably an endemic but neglected infectious disease in Ecuador, especially for the Province of Esmeraldas, and that the real prevalence is completely unknown. The lack of prevalence studies makes public health authorities unware of the risk associated with this neglected tropical disease. In a recent report about worldwide HTLV distribution from the European Center for Disease Control and Prevention, Ecuador was included in the group of countries with non-reliable data for HTLV epidemiology. ${ }^{2}$ With the present publication, we aim to visualize the HTLV problem in Ecuador and raise concerns among public health authorities who have to develop strategies for control, prevention, and treatment of HTLV-1/2 associated diseases. The potential risk of hyperendemicity in our Afro-Ecuadorian population and the risk of transmission to other populations underpins the importance of public health interventions for HTLV control, including the recognition of the HTLV infection among reportable diseases.

\section{Limitations of the study}

This is a preliminary study that aims to raise concerns about HTLV infection and related pathologies in Ecuador. The authors developed and executed this study without any funding from neither universities nor public health institutions, relaying completely on donations from colleagues (especially from the National Institute of Health from Chile). Therefore, this study has some important limitations that, as authors, we consider necessary to detail. We had no access to any diagnosis test to 
distinguish between the HTLV-1 and -2 viruses, neither with a Western blot or HTLV-1/2 specific primers for PCR. Also, specific cell lines, used to distinguish between HTVL-1/2 infection with the IF assay, as has been done in Gallo et al, ${ }^{27}$ were not available. Obviously, to exclude infection, the 17 reactive but not confirmed positive subject in this study should be subjected to an immunoblot confirmation assay. We include only 227 individuals in this study due to limitations in the availability of ELISA tests. We hope that, upon publication of this work, funds will be allocated to study the epidemiology of HTLV 1/2 viruses in Ecuador in a wider population, including not only afro-descendant, but also the indigenous population of Ecuador. We plan to introduce in Ecuador Western blot and nested-PCR protocols for the identification of HTLV-1 and -2. Moreover, for phylogenetic studies, the isolation and sequencing of the HTLV-1 and/or -2 viruses, infecting the Ecuadorian population, has been planned.

\section{Acknowledgments}

We thank "Instituto Nacional de la Salud" from Chile for support with the IF assay.

\section{Author contributions}

All authors contributed toward data analysis, drafting and revising the paper, gave final approval of the version to be published, and agree to be accountable for all aspects of the work.

\section{Disclosure}

The authors report no conflicts of interest in this work.

\section{References}

1. de The' G, Bomford R. An HTLV-I vaccine: why, how, for whom? AIDS Res Hum Retroviruses. 1993;9(5):381-386. doi:10.1089/ aid.1993.9.159

2. European Centre for Disease Prevention and Control. Geographical Distribution of Areas with a High Prevalence of HTLV-1 Infection. Stockholm: ECDC; 2015.

3. Gessain A, Cassar O. Epidemiological aspects and world distribution of HTLV-1 infection. Front Microbiol. 2012;3:388. doi:10.3389/ fmicb.2012.00388

4. Murphy EL, Cassar O, Gessain A. Estimating the number of HTLV-2 infected persons in the world. Retrovirology. 2015;12(Suppl S1):O5. doi:10.1186/1742-4690-12-S1-O5

5. Carneiro-Proietti ABF, Catalan-Soares BC, Castro-Costa CM, et al. HTLV in the Americas: challenges and perspectives. Rev Panam Salud Publica. 2006;19(1):44-53. doi:10.1590/S1020-49892006000100007

6. Murphy EL, Wilks R, Hanchard B, et al. A case-control study of risk factors for seropositivity to human T-lymphotropic virus type I (HTLV-I) in Jamaica. Int $J$ Epidemiol. 1996;25(5):1083-1089. doi:10.1093/ije/25.3.554
7. Gotuzzo E, Verdonck K, González E, Cabada M. Virus Linfotrópico humano de células T tipo 1 (HTLV-1): una infección endémica en el Perú. Rev Peru Med Exp Salud Publica. 2004;21(4):253-260.

8. Alessio L, Minichini C, Starace M, et al. Low prevalence of HTLV1/ 2 infection in a population of immigrants living in southern Italy. PLoS Negl Trop Dis. 2018;12(6):e0006601. doi:10.1371/journal. pntd.0006601

9. Paiva A, Casseb J. Origin and prevalence of human T-lymphotropic virus type 1 (HTLV-1) and type 2 (HTLV-2) among indigenous populations in the Americas. Rev Inst Med Trop Sao Paulo. 2015;57(1):1-13. doi:10.1590/S0036-46652015000100001

10. Yoshida M, Seiki M, Yamaguchi K, Takatsuki K. Monoclonal integration of human T-cell leukemia provirus in all primary tumors of adult T-cell leukemia suggests causative role of human T-cell leukemia virus in the disease. Proc Natl Acad Sci U S A. 1984;81 (8):2534-2537. doi:10.1073/pnas.81.8.2534

11. Gessain A, Barin F, Vernant JC, et al. Antibodies to human T-lymphotropic virus type-I in patients with tropical spastic paraparesis. Lancet. 1985;2(8452):407-410.

12. Goncalves DU, Proietti FA, Ribas JGR, et al. Epidemiology, treatment, and prevention of human T-cell leukemia virus type 1-associated diseases. Clin Microbiol Rev. 2010;23:577-589. doi:10.1128/CMR.00063-09

13. Roucoux DF, Murphy EL. The epidemiology and disease outcomes of human T-lymphotropic virus type II. AIDS Rev. 2004;6:144-154.

14. Proietti FA, Abf C-P, Catalan-Soares BC, Murphy EL. Global epidemiology of HTLV-I infection and associated diseases. Oncogene. 2005;24(39):6058-6068. doi:10.1038/sj.onc.1208968

15. Montesdeoca-Andrade MJ, Correa-Diaz EP, Buestán ME. HTLV1-associated myelopathy in a solid organ transplant recipient. $B M J$ Case Rep. 2016. doi:10.1136/bcr-2016-215243

16. Trujillo JM, Concha M, Muñoz A, et al. Seroprevalence and cofactors of HTLV-I infection in Tumaco, Colombia. AIDS Res Hum Retroviruses. 1992;8(5):651-657. doi:10.1089/aid.1992.8.651

17. Domínguez MC, Salcedo M, García-Vallejo F. Serological and virological evaluation of human T-lymphotropic virus type 1 infection in family groups from Tumaco, Colombia. Biomédica. 2015;35:337-346. doi:10.7705/biomedica.v35i3.2601

18. Bermúdez-Forero MI, Berrío-Pérez M, Herrera-Hernández AM, et al. Prevalence of human T-cell lymphotropic virus I and II in Colombian blood donors, 2001-2014: implications for transfusion safety. Biomédica. 2016;36(Supl.2):194-200. doi:10.7705/biomedica.v36i0.2943

19. Alvarez C, Verdonck K, Tipismana M, Gotuzzo E. A Peruvian family with a high burden of HTLV-1- associated myelopathy/tropical spastic paraparesis. BMJ Case Rep. 2015;bcr2015209619. doi:10.1136/ bcr-2015-209619

20. Guderian R, Guevara A, Cooper P, Rugeles MT, Arango C. HTLV-1 infection and tropical spastic paraparesis in Esmeraldas Province of Ecuador. Trans R Soc Trop Med Hyg. 1994;88:399-400. doi:10.1016/ 0035-9203(94)90398-0

21. Alarcón-Guzmán T, Alarcón-Avilés T. Tratamiento de la Paraparesia Espástica Tropical con Pentoxifilina: estudio Piloto. Rev Neurol. 2002;11(1):1-3.

22. Alarcón T, Hidalgo C, Aguirre R, Díaz E, Santibáñez R, Navas C. Mielitis Crónica por HTLV-1: resultados en 45 Casos Estudiados. Rev Neurol. 2007;16(3)1-11.

23. San Martín H, Balanda M, Vergara N, Valenzuela MA, Cartier L, Ayala S, Ramírez E. Human T-Lymphotropic Virus Type 1 and 2 Seroprevalence among first-time blood donors in Chile, 2011-2013. J Med Virol. 2016;88(6):1067-1075. doi:10.1002/jmv.24428

24. Matsumoto C, Mitsunaga S, Oguchi T, et al. Detection of human T-cell leukemia virus type I (HTLV-I) provirus in an infected cell line and in peripheral mononuclear cells of blood donors by the nested double polymerase chain reaction method: comparison with HTLV-I antibody tests. J Virol. 1990;64 (11):5290-5294 
25. Gallegos S, Mangano A, Gastaldello R, Sen L, Medeot S. Usefulness of a Nested-polymerase chain reaction for molecular diagnosis of human T-cell lymphotropic virus type I/II. Mem Inst Oswaldo Cruz. 2004;99(4):377-380. doi:10.1590/S0074-02762004000400006

26. Ramirez E, Cartier L, Villota C, Fernandez J. Genetic characterization and phylogeny of human T-cell lymphotropic virus type I from Chile. Virus Res. 2002;84(1-2):135-149. doi:10.1016/S0168-1702(02)00005-9
27. Gallo D, Penning LM, Hanson CV. Detection and differentiation of antibodies to human T-cell lymphotropic virus types I and II by the immunofluorescence method. $J$ Clin Microbiol. 1991;29 (10):2345-2347.

\section{Publish your work in this journal}

Infection and Drug Resistance is an international, peer-reviewed openaccess journal that focuses on the optimal treatment of infection (bacterial, fungal and viral) and the development and institution of preventive strategies to minimize the development and spread of resistance. The journal is specifically concerned with the epidemiology of antibiotic resistance and the mechanisms of resistance development and diffusion in both hospitals and the community. The manuscript management system is completely online and includes a very quick and fair peerreview system, which is all easy to use. Visit http://www.dovepress.com/ testimonials.php to read real quotes from published authors. 